Meta

Journal des traducteurs

Translators' Journal

\title{
A Psychological Approach to Consecutive Interpretation
}

\section{Deborah A. Garretson}

Volume 26, numéro 3, septembre 1981

URI : https://id.erudit.org/iderudit/002808ar

DOI : https://doi.org/10.7202/002808ar

Aller au sommaire du numéro

Éditeur(s)

Les Presses de l'Université de Montréal

ISSN

0026-0452 (imprimé)

1492-1421 (numérique)

Découvrir la revue

Citer cet article

Garretson, D. A. (1981). A Psychological Approach to Consecutive Interpretation. Meta, 26(3), 244-254. https://doi.org/10.7202/002808ar d'utilisation que vous pouvez consulter en ligne.

https://apropos.erudit.org/fr/usagers/politique-dutilisation/ 


\section{A Psychological Approach to Consecutive Interpretation*}

Deborah A. Garretson

Although there has been growing interest in recent years in a "psychological' approach to translation and, in particular, to simultaneous interpretation, such an approach has not yet been attempted with regard to consecutive interpretation ${ }^{1}$. Yet the techniques and methodology tried and tested over the years in the profession of consecutive interpreting are now finding confirmation and elaboration in recent research and hypotheses developed in the fields of psycholinguistics and of the psychology of memory and attention.

In addition to the basic tasks common to all forms of translation activity, consecutive interpretation, because of the added factors of the temporal sequence of the translation and the necessity for note-taking, draws on cognitive faculties of memory and attention which are not typical of other forms of translation. Like other forms of translation, consecutive interpretation thus requires not a transposition nor a re-coding of the original message, but rather, as Professor Lederer of the Sorbonne has pointed out, its re-statement, re-expression in the target language ${ }^{2}$. In translation, as Professor Lederer's colleague, Professor Pergnier put it, the 'parole' becomes thought in order for the thought to become once more 'parole' 3 . The basic activity then of the translator, as Professor Pergnier so ably formulated it, involves three necessary operations ${ }^{4}$ :

1. the perception and 'analysis' of the 'signifié'

2. the 'exegesis' of the meaning and 'oubli' of the original 'signifiant'

3 . the reformulation in the medium of the target language of the meaning extracted from the 'exegesis'.

Investigation of the necessary operation of the 'exegesis' of the meaning of the message to be translated provided fruitful common ground for translators

\footnotetext{
* The title of this paper has been inspired by the article appearing in this journal by D. Gerver, "A Psychological Approach to Simultaneous Interpretation", Meta 20 (1975) 2, 119-128.

1. See, in particular, the work of D. Gerver 1974, 1975, 1976. Others active in the United States and Canada are H. C. Barik 1971, 1972, 1973; E. A. Lawson 1967; F. Goldman-Eisler 1972a and 1972b; A. Treisman 1965. Some work has been conducted in France : Oléron and Nanpon 1965. Work in the Soviet Union is represented primarily by G. V. Cernov 1978. Two extremely useful collectoins of articles are to be found in R. Brislin, ed. 1976 and D. Gerver and H. W. Sinaiko, eds. 1978

2. Cf. the title of the article by M. Lederer, "La traduction : transcoder ou réexprimer?" 1973.

3. See Pergnier 1973.

4. See Pergnier 1973.
} 
and linguists of the emerging school of transformational grammar in the 1960 's ${ }^{5}$. Of particular importance for our consideration here, however, is the emphasis on 'oubli', or as Professor Seleskovitch terms it, the 'rejet' of the original 'signifiant' 6 :

Nous voyons ici un premier exemple de la rétention du sens accompagnée d'un rejet des mots : une note est prise, une forme est donc présente mais il ne s'agit plus d'une traduction comme dans le cas des notes verbales, il s'agit d'une forme verbale découlant du concept.

Like her predecessor in the profession, J.-F. Rozan, Professor Seleskovitch is emphasizing the cardinal importance of 'la transposition de l'idée plutôt que du mot' in consecutive note-taking 7 , and goes on to urge that notes should be brief and should not reflect the linguistic structures of the perceived message ${ }^{8}$.

Implicit to the methodology of note-taking, then, is the notion of the conversion of a given message into its basic conceptual units, into a, so to speak, conceptual form, or as linguists would describe it, into its underlying abstract form. The interpreter must decode the message into its abstract form before undertaking translation, before proceeding to encode the message into the target language. It is thus clear that the intermediary step of all translation activity, that of the exegesis, finds, in consecutive interpretation, further extension and elaboration : it is recorded in external form in the notes of the interpreter. The principles of both underlying form and of the rejection, the transitoriness, of the external message are amongst the issues which have been at the very center of research conducted in the sixties and seventies in the fields of psycholinguistics and the psychology of memory.

With the advent of transformational grammar and a model of language based on the premise of two levels of linguistic structures (deep and surface structure), connected by grammatical rules, linguists undertook the task of testing the psychological reality of the postulated rules. The experiments devised tested sentence recall; memory for sentences was used as a test for the validity of transformational rules as sequences of mental processes in comprehension and retention. The results of this work, designed more with an aim to testing linguistic hypotheses than to elaborating a theory of memory, have nonetheless provided valuable insights into the properties of short and long term memory and and of their roles in the perception and comprehension of sentences.

It was found that verbatim recall, that is, memory for the surface structure of the sentence, is a function of two factors : $1^{\circ}$ the interval of time elapsing between the presentation of the material and the time of recall; and $2^{\circ}$ the kind of task set the subjects of the experiment ${ }^{9}$. The memory for surface structures and its features undergoes rapid decay ${ }^{10}$, and it is only by means of special

5. See, among others, Nida 1964, Nida and Taber 1969 and Walmsley 1970.

6. Seleskovitch 1975, p. 75.

7. Rozan 1959 , p. 13.

8. Seleskovitch 1975 , p. 139

9. See Sachs 1967, P.N. Johnson-Laird and R. Stevenson 1970, and G. B. Flores d'Arcais 1974.

10. See G. A. Miller 1956. 
strategies devised by the subjects that this decay can to some degree be counteracted $^{11}$.

The wording, the surface structure of the sentences, is largely lost by the subjects within a short time after presentation; yet when questioned about the content of the material presented, the subjects were able both to recognize as well as actively recall their contents with accuracy. In experiments involving recognition of the sentences originally presented, the subjects had difficulty in identifying the exact wording of given sentences, but were able to detect any changes in meaning. Similarly, in tests involving recall, the subjects frequently furnished sentences bearing little structural similarity with the original, yet rarely diverging from them in semantic content ${ }^{12}$.

The subjects thus seem to have extracted the meaning of the material from its external form, stored this information in an abstract form, and, in the course of recognition and recall, reconstructed the stored material afresh, imposing on it a new grammatical and syntactic structure.

Indeed, it is only to the interpreter's advantage to possess and constantly develop acute powers of recall, but in so doing the interpreter is exceeding, in fact, overcoming, the limits of normal language use. The evidence points to a rapid decay of verbatim memory and to the process of recall as the retrieval of information stored in abstract form. Both Professor Seleskovitch's recommendation of 'rejecting' the external form of expression, and Rozan's counsel of noting down the concept rather than the word are confirmed by these findings.

It has yet to be established in what form semantic material is stored in memory, and researchers are still uncertain of the properties of, and the interrelationships between, different types of memory ${ }^{13}$. Long term memory seems to involve recall of the meaning of the perceived message, and is essentially reconstructive by nature, whereas short term memory seems to perform both the function of verbatim recall (the memory for surface rather than deep structure) as well as functions necessary to the decoding of the message (a capacity often termed 'working memory'). In the latter case it thus seems to involve recall for deep structure as well, for recent hypotheses maintain that perception and comprehension involve the active construction by the listener of the possible underlying representation of the surface structure of the message as it proceeds ${ }^{14}$ :

During a clause we accumulate information and hypotheses concerning its potential deep structure; at the end of the clause, we decide on the structure of what we just heard.

11. This paper does not deal with this problem as such, yet the extreme importance of such strategies, particularly in consecutive interpreting, cannot be minimized, and require further study.

12. See Sachs 1967 and Flores d'Arcais 1974

13. I have used the terms 'verbatim memory' and 'long' and 'short term memory' rather loosely here for our purposes. One should more precisely speak of verbatim memory as 'short term memory'; for a discussion of the terminology see F. I. Craik and B. A. Levy 1976. Research on these problems is growing and changing rapidly, with little consensus on the best model for long term memory and whether information is stored in the form of propositions or as analogues of visual of experience. For a recent summary see Lachman, Lachman and Butterfield 1979.

14. See T. G. Bever 1972. 
In the process of such construction the external form of the message is erased from short term memory.

The interpreter is thus performing operations common to normal language use in the perception and comprehension of the message to be translated, but he or she must take such an operation one step further by making a record of this underlying or semantic representation in the form of notes. The transcription of such a representation ensures a more complete and accurate record of what has been said than the rapid decay of short term memory might normally permit, and the interpreter can then safely proceed to the translation of the message at the end of the speech. We are dealing here not with a re-coding nor a transposition, as mentioned earlier, but with reformulation and re-expression. Translation is not possible without a decoding of the message into its underlying, conceptual form : translation is not possible without (in the case of consecutive interpretation, a record of the result of the) exegesis.

The interpreter's notes thus mirror the exegesis performed by the interpreter in the process of comprehension, and deserve further study. Indeed, the systems of notation devised and the methodology of their application ar relevant to yet another domain of linguistic research : semantics.

In attempting to define the inter-relationships between deep and surface structure and to elaborate the details of transformational rules, linguists became increasingly aware of the semantic and extralinguistic factors motivating the rules of syntax. Convinced that there must be some other abstract mode, or possibly level, constituting sentence meaning, they began to focus their attention on the problems of semantics. Most linguists are still committed to the concept of deep-to-surface structure transformations, but many are convinced that this deep structure representation is of a semantic and not syntactic nature.

The growing conviction that it will not be possible to understand language use without further investigation of the roles of semantics and extralinguistic factors (referred to as 'pragmatics') ${ }^{15}$ in language has brought linguists into the broader field of semantic memory. Psychologists and artificial intelligence specialists, in their study of semantic memory, are examining how general conceptual information, world knowledge and linguistic abilities are preserved in memory. Some of the models developed in this field, based on the informationprocessing paradigm and drawing extensively on work in artificial intelligence, are quite ambitious in scope. They attempt to deal not simply with the permanent structure of memory, but with the full range of human comprehension, including the acquisition of new information and its integration into old information, a topic with obvious and significant import for all forms of interpretation. The research conducted thus far is still decidedly controversial and qualifies more as probes and hypotheses than as models, but many look to it with interest and encouragement, for the right questions are being raised and brought into focus.

15. Pragmatics is intended to treat the systematic interaction of sentences with their contexts, as well as involving judgments revolving on factual assumptions. 
Much of the recent work conducted in this broad field has drawn extensively on mathematical logic, as a means of formalizing the semantics of natural language. It is maintained that the meaning of a sentence or text can be more effectively captured by lists of propositions as in logic. Since the same thing can be said in several ways in natural language, and since the language user retains the content rather than the form of what is perceived and heard, it is maintained that a series or list of propositions can more effectively capture the semantics of a sentence or text ${ }^{16}$. The proposition in this case is not intended as a sentence or string of words; it is assumed to have a non-verbal, nonlinguistic form in the mind and contains one or more concepts and their interrelationships. Such concepts are, however, easily expressible as words. Drawn as it is from mathematical logic, however, the propositional notation as it is presently formulated, cannot accommodate expression in natural language, which can be vague, metaphorical or intentionally ambiguous.

The proponents of such a theory readily admit that they have yet to provide specific and precise rules for the conversion of natural utterances into such a propositional notation.

At issue most recently amongst the various branches of research in psycholinguistics, semantics and artificial intelligence is a common core of problems : $1^{\circ}$ whether semantic theory can be effectively based on the concept of the decomposition of the word into more primitive semantic features, or $2^{\circ}$ whether meaning, as it is represented in the mind, is better described in terms of logical relations, that is, in propositional form.

The advantages of a decompositional approach are varied. It is generally accepted that the meanings of words can be expressed in terms of a combination of simpler concepts. Such basic concepts (variously termed semantic 'units', 'features', 'components', 'primitives') are envisioned as a restricted set of units of meaning, capable of describing the meanings of words in language. As in phonology, where sounds are composed of bundles of features, so too can a word be reduced to a bundle of semantic features. The earliest systematic treatments of this approach are to be found in Katz and Fodor (1963) and Katz and Postal (1964). To illustrate one can compare the meanings of the oft-cited examples man, woman, boy, girl. The meanings of each of these words, and the systematic relations of their meaning, can be reduced to the varying combinations of a limited number of basic features :

1) human (vs. non-human)

2) male (vs. non-male)

3) adult (vs. non-adult)

Man would thus include the features 1. human 2. male 3. adult

Woman would include 1 . human 2 . non-male 3 . adult

Boy would include 1. human 2. male 3. non-adult

Girl would include 1. human 2. non-male 3. non-adult

16. In particular Lakoff, 1972. 
A further, more complex, example can be found in the verbs give and sell: the verb give can be decomposed into the concepts :

$Z$ cause ( $X$ have $Y$ ) for free

Sally $(\mathrm{X})$ gives John $(\mathrm{X})$ the book $(\mathrm{Y})$

Whereas sell can be broken down into all the above components with the exception of the concept 'for free', for which one must substitute 'in exchange for money'. The distinguishing feature in such a bundle of features for the verb loan would thus be 'with promise of return': $Z$ cause ( $X$ have $Y$ ) with promise of return.

The weaknesses of a decompositional approach, however, have been exposed. It is argued in the first place that decomposition is not "psychologically real' for the language user; that is, the language user does not carry out the mental process of decomposition in perceiving and comprehending verbal messages. Lexical items which are more complex in their combination of features have not proved any more difficult to comprehend that simple lexical items ${ }^{17}$. In the second place it is argued that not all semantic relations, that is, relations between meanings, can be explained in terms of independent items of meaning and their combinations into wholes. In particular, relations of containment and entailment cannot be described in terms of semantic features. The well known example of the names of colors can serve as an illustration ${ }^{18}$.

The concept of red cannot be decomposed into independent components : to say something is red is not to say that it is both colored and red. Being red entails being colored, and the component colored cannot be subtracted from the component red. Relations of this type then cannot be captured by decompositional analysis and call for a different approach to semantic relations.

For these reasons the proponents of propositional representation argue in favor not of lexical decomposition, but of the 'meaning postulate'. The 'meaning postulate', as initially conceived by logicians ${ }^{19}$ is intended as a set of inference rules in a logical system to cover extra-logical relations. Their particular usefulness in linguistics lies in their ability to express those entailment relations between words which are not bi-directional. To take up our earlier example :

$$
\begin{aligned}
\text { Man } & \rightarrow \text { human } \\
& \rightarrow \text { male } \\
& \rightarrow \text { adult }
\end{aligned}
$$

The above notation may seem to be but a variation on decomposition. However, meaning postulates do not reduce the word to primitive, atomic concepts, as in lexical decomposition; instead they provide a set of inference rules (or axioms) associated with the word, rather than defining a word in terms of individual features.

17. Kintach 1974 .

18. See J. D. Fodor $1977,5.1$

19. Carnap 1964. 
The greatest usefulness of meaning postulates is their ability to express not only those cases where lexical decomposition is an effective means of analysis as above, but also in those instances where there is no such bi-directional entailment, as in the case of red :

red

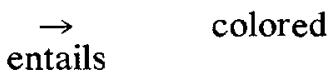

In the case of man the entailment is bi-directional, an entailment implicit to decompositional analysis : not only does man entail the features human, male, and adult, but the reverse - the summation of the features human, male and adult entail man. This is not the case with red, where the relationship is not bidirectional : red cannot be factored in the same manner into the features colored and red, nor is there any way to extract a combination of features which would incontrovertibly entail red.

Opinions concerning the usefulness and versatility of meaning postulates vary considerably among linguists and psycholinguists. Indeed, it has yet to be proved that the meaning postulate can capture meaning relationships in semantics other than those of entailment (and the field is broad, including the problems of ambiguity, anomaly and redundancy) ${ }^{20}$. Some linguists suggest a combined approach of both lexical decomposition and meaning postulates, like Lakoff ${ }^{21}$.

In any event, the shift of interest from the definitional analysis of lexical decomposition to that of the inference rules of the meaning postulate is of particular importance to an understanding of the process of comprehension. The approach of lexical decomposition implies that the language user, in comprehending a verbal message, undertakes the process of replacing the defined term (word) with its defining terms (features), that the process of decomposition is 'psychologically real', as mentioned earlier. Lexical decomposition thus posits the premise that difficulty of comprehension directly corresponds to the complexity of features of the perceived word. This, however, has not been borne out ${ }^{22}$.

In particular, Kintsch ${ }^{23}$ found that complex and simple words ('derived' and 'non-derived' in his terminology) were

...equally difficult in terms of generating a sentence from a given word completing sentences, sentence comprehension and memory.

He thus points out that ${ }^{24}$

A theory of memory in which both derived and nonderived words are represented in the same way as lists of propositions specifying their use agrees best with these results.

$\mathrm{He}$ is thus arguing that complex and simple words alike are treated as unitary concepts.

20. J. D. Fodor 1977.

21. Lakoff 1972 .

22. Among others, see J. A. Fodor 1979, $148 \mathrm{ff}$.

23. Kintsch 1974 , p. 240.

24. Ibid. 
In a further experiment, Kintsch was able to establish that, if the task requires it, the language user does indeed perform the mental processes of decomposition on complex words, but does not draw on this process unless it is required by the task at hand. It thus seems that in comprehension propositional representations are formed without the decomposition of the lexical units involved. Kintsch concedes that in memory words may indeed be preserved in decomposed form, but they are not automatically decomposed during comprehension. Thus in sentence comprehension one is dealing not with a decoding into semantic features, but into meaning postulates, upon which the listener can draw if circumstances require it. As J.A. Fobor has put it ${ }^{25}$

...understanding a sentence involves computing a representation of the sentence that determines its entailments; it doesn't involve computing the entailments. (It couldn't; there are too many of them.)

What these researchers are suggesting then is a language of internal representation in the comprehension and production of speech which is less removed from the surface structures of natural language than has been envisioned thus far by linguists and psycholinguists.

Even a brief examination of the notation systems and symbols used in consecutive interpreting point out this same core of problems ${ }^{26}$. The use of individual symbols or abbreviations to render a complete range of semantic clusters seems to support a decompositional approach. The symbols "(to render the cluster express, declare, state, maintain, say, announce), and: (to render think, consider, feel, evaluate), for instance, provide ready examples of the decomposition of the word to be translated to it minimal, invariant component. A particularly striking example of this process can be found in the use of the upward and downward arrows, as illustrated by Rozan ${ }^{27}$ :

$\begin{array}{ll}\rightarrow \text { d'un pays } & \text { (development of country) } \\ \rightarrow \text { science } & \text { (progress in science) } \\ \rightarrow \text { malade } & \text { (convalescence of the ill) } \\ \rightarrow \text { salaries } & \text { (increase in salary) } \\ \rightarrow \text { level vie } & \text { (improvement in living standards) } \\ \rightarrow \text { prix } & \text { (rise in prices) }\end{array}$

The lexical items and phrases have been reduced to their major common component, with a notation of the distinguishing feature(s). The symbol can thus render a broad range of synonyms and contextual variants of a given semantic cluster (increase, recovery, upswing, expansion, development, progress, improvement, rise) whose form in the target language (i.e. whose translation) can be determined, even without a notation of the distinguishing features, by contextual factors.

A closer examination of the interpreter's notes, however, confirm the limitations of a decompositional analysis. Interpreters in their notes not only

25. J. A. Fodor 1979, p. 150

26. Rozan 1959 , p. 32.

27. Ibid. 
make broad use of abbreviations, but also frequently treat complex words as unitary concepts ${ }^{28}$ :

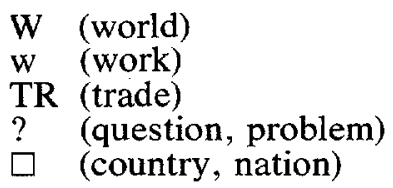

We have attempted here to give a survey of points deserving further examination, with an indication of a possible framework of approach to these problems. It seems fairly clear that the decoding performed by the interpreter in note-taking, and the techniques employed, point to the conclusions reached by Kintsch and Fodor. As in the process of comprehension, the interpreter, in taking his or her notes, is computing a representation of the sentence representative of its entailments. Although these entailments are not spelled out (and could not be, because of the time factor in the interpreter's task), they are available to the interpreter in the form of notes should her or she need them for the translation task at hand.

\section{BIBLIOGRAPHY}

BARIK, H.C. (1971): "A description of various types of omissions, additions, and errors encountered in simultaneous interpretation", Meta 16, 119-128.

BARIK, H.C. (1972): "Some innovations in a computer approach to the analysis of speech patterns", Language and Speech 15, 196-208.

BARIK, H.C. (1973): "Simultaneous interpretation: temporal and qualitative data", Language and Speech 16, 237-270.

BEVER, T.G. (1972): "Perception, Thought and Language", in Carroll and Freedle (1972), 99-112.

BRANSFORD, John D., J. Richard BARCLAY and J.J. FRANKS (1972): "Sentence memory : a constructive versus interpretive approach", Cognitive Psychology 3, 193-209.

BRISLIN, Richard W., ed. (1976): Translation, Applications and Research, N.Y., Gardner Press,

BROWER, R.A., ed., (1966); On Translation, N.Y., Oxford University Press.

CARROLL, John B. and Roy O. FREEDLE, eds. (1972): Language Comprehension and the Acquisition of Knowledge, Washington D.C., V.H. Winston \& Sons.

CERNOV, G.V. (1978) : Teorija i praktika perevoda, Moscow, Meždunarodnye otnošenija.

CRAIK, F.I. and B.A. LEVY (1976): "The concept of primary memory," in Estes, ed. (1976), 133-36.

DAVIDSON, Donald and Gilbert HARMAN, ed. (1972): Semantics of Natural Language, Dordrecht, D. Reidel Publishing Co.

ESTES, W.K., ed. (1976) : Handbook of Learning and Cognitive Processes, vol. 4, Attention and Memory, Hillsdale, N.J., Lawrence Erlbaum Associates.

FLORES D'ARCAIS, G.B. (1974): "Is there a memory for sentences?", Acta Psychologica 38, 33-58.

FODOR, Janet Dean (1977): Semantics : theories of meaning in generative grammar, New York, Thomas E. Crowell Co.

FODOR, Jerry A. (1979) : The language of thought, Cambridge, Mass., Harvard University Press.

28. Rozan 1959 , p. 35. See also Ryle 1951 for a discussion of lexical decomposition and of those categories which cannot be defined in terms of more primitive properties. 
GERVER, D. (1974): "The effects of noise on the performance of simultaneous interpreters : accuracy of performance", Acta Psychologica 38, 159-167.

GERVER, D. (1975) : "A psychological approach to simultaneous interpretation," Meta $20,2,119-128$

GERVER, D. (1976): “Empirical studies of simultaneous interpretation: a review and a model," in Brislin (1976), 165-207.

GERVER, D. and H. Wallace SINAIKO, eds. (1978) : Language Interpretation and Communication, N.Y. and London, Plenum Press.

GOLDMAN-EISLER, F. (1972a) : "Segmentation of input in simultaneous interpretation", Journal of Psycholinguistic Research 1, 127-140.

GOLDMAN-EISLER, F. (1972b): "Pauses, clauses and sentences", Language and Speech 15, 103-113.

HERBERT, J. (1952): The Interpreter's Handbook, Geneva, Georg \& Cie.

JAKOBSON, Roman (1966): "On linguistic aspects of translation", in Brower (1966), 232-239.

JAKOBSON, Roman (1971) : "Zeichen und System der Sprache', Selected Writings II, The Hague, Mouton, 272-279.

JOHNSON-LAIRD, P.N. and R. STEVENSON (1970) : "Memory for syntax", Nature 227, 412

KATZ, J.J. and J.A. FODOR (1963): "The structure of semantic theory", Language 39, 170-210.

KATZ, J.J, and P.M. POSTAL (1964) : An integrated theory of linguistic descriptions, Cambridge, Mass., MIT Press.

KINTSCH, W. (1974): The representation of meaning in memory, Hillsdale, N.J., Lawrence Erlbaum Associates.

LACHMAN, Roy, Janet L. LACHMAN and Earl C. BUTTERFIELD (1979): Cognitive Psychology and Information Processing, Hillsdale, N.J., Lawrence Erlbaum Associates.

LAKOFF, George (1972): "Linguistics and natural logic", in Davidson and Harman (1972), 545-665.

LAWSON, E.A. (1967): "Attention and simultaneous translation", Language and Speech 10, 29-35.

LEDERER, M. (1973): "La traduction : transcoder ou réexprimer?", Études de linguistique appliquée $12,18-25$.

LONGLEY, P. (1968) : Conference Interpreting, London, Pitman.

MEHLER, J. (1963): "Some effects of grammatical transformations on the recall of English sentences", Journal of Verbal Learning and Verbal Behavior 2, 346-51.

MILLER, G.A. (1956): "The magic number 7, plus or minus 2", Psychological Review 63 81-97.

MILLER, G.A. (1962): "Some psychological studies of grammar", American Psychologist $17,748-62$.

MILLER, G.A. and P.N. JOHNSON-LAIRD (1972) : Language and Perception, Cambridge Mass., Harvard University Press.

MIN'JAR-BELORUCEV, R.K. (1969) : Posledovatel'nyj perevod, Moscow, Voenizdat.

NIDA, E. (1964): Toward a Science of Translating, Leiden, E.J. Brill.

NIDA, E. and C. TABER (1969): The Theory and Practice of Translation, Leiden, E.J. Brill.

OLÉRON, P. and H. NANPON (1965): "Recherches sur la traduction simultanée", Journal de psychologie normale et pathologique 1, 73-94.

PERGNIER, M. (1973): "Traduction et théorie linguistique", Études de linguistique appliquée $12,28-38$.

ROZAN, J.-F. (1959) : la Prise de notes en interprétation consécutive, Geneva, Georg \& Cie.

RYLE, G. (1951): "Thinking and language," Proceedings of the Aristotelian Society, Supplementary volume $25,65-82$.

SACHS, J. (1967): "Recognition memory for syntactic and semantic aspects of connected discourse", Perception and Psychophysics 2, 437-442.

SAVIN, F.B. and E. PERCHONOCK (1965): "Grammatical structure and the immediate recall of English sentences", Journal of Verbal Learning and Verbal Behavior, 4, 348-53.

SCHANK, Roger C. (1975): Conceptual Information Processing, Amsterdam, North Holland Press.

SELESKOVITCH, D. (1975) : Langage, langues et mémoire, étude de la prise de notes en interprétation consécutive, Paris, Lettres modernes.

SELESKOVITCH, D. (1976): "Interpretation, a psychological approach to translation", in Brislin (1976), 92-116. 
TREISMAN, A. (1965): "The effects of redundancy and familiarity on translating and repeating back a foreign and a native language", British Journal of Psychology 56, 369-79.

WALMSLEY, J. (1970) : "Transformation theory and translation", International Review of Applied Linguistics in Language Teaching 8, 3, 185-9. 